DOI https://doi.org/10.32841/2409-1154.2021.49-2.2

\author{
Skrypnyk L. V., \\ Senior Lecturer at the Department of Ukrainian Language and Language Training of Foreign Citizens \\ Kharkiv National University of Civil Engineering and Architecture
}

\author{
Khodakivska M. O., \\ Senior Lecturer at the Department of Ukrainian Language and Language Training of Foreign Citizens \\ Kharkiv National University of Civil Engineering and Architecture
}

Chernohorska N.G., Senior Lecturer at the Department of Ukrainian Language and Language Training of Foreign Citizens Kharkiv National University of Civil Engineering and Architecture

\title{
SOME ASPECTS OF WORKING WITH TEXTS IN THE PROCESS OF STUDYING A LANGUAGE OF SPECIALTY IN A TECHNICAL UNIVERSITY IN GROUPS WITH ENGLISH AS THE LANGUAGE OF INSTRUCTION
}

Summary. The article deals with the problems of working with texts in the specialty in the system of teaching the language of instruction at a Technical University. The purpose of this study is to analyze and systematize the main aspects and difficulties of working with texts in the specialty in language classes at a Technical University, and the system of work on designing a special scientific text used by the authors of the study is presented.

Since the purpose of training foreign students of a Technical University in the language of instruction classes is to form communicative competence, primarily in the professional sphere of communication, the task of teachers of the department is to teach and develop the ability of foreign students to understand and produce scientific texts in the specialty. After all, in the process of professionally oriented training, the personality of a future engineer or architect is formed, and this person should be capable of productive professional communication in both their native and foreign languages. But teachers should also pay attention to the fact that foreign applicants for higher education often show a low level of skills and abilities to work with professionally oriented texts both in the learning process and during exams.

The scientific text in the specialty, which is the subject of the analysis of this study, makes it possible to harmoniously combine exercises for developing language skills and working with scientific text in the learning process, and should also be a source of up-to-date, professionally significant information. Texts should give the teacher the opportunity to use them in the classroom as material for observation, analysis, comprehension, training of language skills and abilities, as well as monitoring the material studied. The authors of the article focus on independent work of students in the classroom, reading texts of any level of complexity, on understanding, and not on reproducing the text.

The authors also conclude that systematic work with the text in the specialty is a leading component of teaching students in language classes in the main courses, develops skills in reproducing and producing texts, and contributes to the formation of communicative competence in the professional sphere.

The article analyzes the experience gained by the Department of Ukrainian language and language training of foreign citizens in the field of teaching the language of instruction and defines the prospects for further methodological work.

Key words: language of instruction, scientific text, text by specialty, professional communication, communicative competence.

Urgency of the research. The relevance of this study lies in the fact that language of education for foreign students is not only an academic subject, but also a way of personal development, an opportunity to acquire professional competencies and in the scientific and methodological literature devoted to the study of language of education there is a lack of specific methodological recommendations for teaching reading texts on specialty which would help to optimize the learning process.

As the aim of training foreign students of a technical university in language of education is to form communicative competence, first of all, in the professional sphere of communication, the task of our department teachers is to teach and develop the ability of foreign students to understand and produce scientific texts on the specialty [1].

In fact, the personality of a future engineer or architect is formed in the process of profession-oriented education, and this personality should be capable of productive professional communication both in the native language and in a foreign language.

Problem of the article. Despite the large number of studies on the methods of studying scientific style of speech and texts on specialty in the classes of language of education, foreign students often show a low level of skills and abilities to work with professionally oriented texts both in the learning process and when passing exams.

Teachers of language often have to hear comments from teachers of different departments of the university about how poorly foreign students speak language of education and scientific terminology in the professional sphere at the presentation the diplomas. That is why special attention needs to be paid to the formation and development of skills of independent reading of texts on specialty.

Results and discussions. The issue of mastering a specialty language and the quality of training highly qualified specialists is one of the most complex and topical question in the method- 
ology of teaching language of education and has repeatedly attracted the attention of methodologists and researchers (works by E.I. Motina, L. Bey, I. Kochan, D. Mazurik, T. Laguta, B. Sokol, E. Trostinskaya, G. Tokhtar, N. Stankevich). Today's research in the field of teaching professional texts in a foreign language is presented in a certain way in scientific work K. Kusko, T. Yakhontova and others. The number of textbooks with developed and competent methodological practices has increased significantly over the past decade.

The practical significance of our study lies in presenting a system of works on the construction of a special scientific text by analyzing and systematizing the main aspects and difficulties of studying a specialty text in the classes of the language of education in a technical university.

Material and methods. At the department of the Ukrainian language and language training of foreign citizens of the Kharkiv National University of Civil Engineering and Architecture tutorial and basic textbooks were prepared for practical classes in language of education, which contain carefully selected texts on architecture and construction specialties: L. Skripnik, N. Chernogorskaya Step into the profession: Practicum on speech development for foreign applicants of higher education specialty 192 "Construction and civil engineering"; E. Belikova, N. Bessonova, O. Greul Step into the profession: Practicum on speech development for foreign applicants of higher education specialty 191 "Architecture and urban planning".

I. Mileva, M. Khodakovskaya [2], who are the authors of methodological recommendations for independent reading of adapted texts by foreign students, paid attention to the development of reading skills and the practical aspect of this type of reading in the lessons of Ukrainian as a foreign language. (Ignatova V.V., Krech T.V., Martinova I.E., Mileva I.V., Khodakivska M.O. Learning Ukrainian: Textbook of Ukrainian as a foreign language for students specialties 191 "Architecture and Construction", 192 "Construction and Civil Engineering"). This publication consists of three sections and contains 19 adapted narrative texts for reading by foreign-language students, which are accompanied by preand post-textual assignments.

Also, the material of the study include the scientific texts on special disciplines ("Construction Materials", "Engineering Geodesy", "Construction and Theoretical Mechanics", "Architectural Structures", "Design of Architectural Environment", etc.), studied by students of specialties 191 "Architecture and Urban Planning" and 192 "Construction and Civil Engineering" textbooks and scholarly research on the problem of studying texts in the specialty, compiled by L. Skripnik, N. Chernogorskaya [3], as well as E. Belikova, N. Bessonova, and O. Greul [4].

Research methods - empirical, theoretical, pedagogical, such as observation of the process of studying special texts in the classes of language of education by students of the main courses, interviewing students, analysis and synthesis of scientific literature, textbooks on the study of special texts in the classes of Ukrainian language as a foreign language, conversations with teachers of special disciplines of foreign students.

Results of the study and their discussion. Working with professionally oriented texts always causes great difficulties for foreign students. As M. Sokol and N. Pakhomova rightly point out, "foreign students study at the preparatory department before entering the first year of university... but it is very difficult and almost impossible to achieve such a level of proficiency in a special language that would allow foreign students to easily join the educational process on a par with Ukrainian students] [5, p. 58]. Often teachers of language face the problem of late arrival of students to the preparatory department - instead of the planned language of education classes from October 1, students start studying in March or even in April and three months later start their first year.

The problem of forming professional competences in the process of studying language of education is also relevant to the process of teaching language of education to foreign students in the main courses of studying language of education. Sometimes we have to deal with dissatisfaction of teachers of special disciplines, who do not understand why foreign student does not fully learn the terminology of his/her subject.

The list of disciplines, which the 1st year student of technical university begins to study, is rather big: higher mathematics, physics, informatics, introduction to specialty, etc. It is not possible to study the terminology of these and other disciplines fully in classes in language of education, though teachers of the department of Ukrainian language and language training of foreign citizens of our university maintain close relations with subject teachers.

Listening to and recording the teacher's audio speech is very difficult for foreign students. Reading a non-adapted specialty text is also a very difficult task for students. Meanwhile, the student should successfully learn the disciplines of the specialty, while experiencing minimal difficulties in terms of knowledge of the language of education, listening to lectures, preparing reports and presentations, giving speeches, asking and answering questions, defending one's own opinion.

Before starting to work with the text on the specialty, the student must have an idea of scientific style of speech in general, learn the basic general scientific vocabulary, learn structural and syntactic models of scientific text (qualification of the phenomenon, subject; device, purpose, etc.) and the most typical ways of their expression, be able to operate with language constructions that provide logical connectivity of statement (temporal, target, determinative, causal, conditional, etc. relations). Students must have an idea of the main ways of presenting information in a scientific text (description, reasoning, narration) in order to understand how the syntactic structure of each of them is implemented, which means ensure the logicality and coherence of the text [6].

It is necessary to form skills and abilities among foreign students to use scientific literature in their specialty in order to obtain information for the creation of secondary texts: abstracts, summaries, theses, reviews, term papers and graduation papers in Ukrainian.

The basis for the formation of speech skills in the field of reading, writing, listening, speaking and their further improvement in the learning process is always a text (educational-scientific, general scientific, special scientific text). The basis of professionally oriented teaching of language of education in a technical university is also based on texts. A text is a model of how language functions. In the communicative approach, it is the initial and final unit of educational process. As E. Motina notes, "the meaning of a scientific text in teaching language of education is multifaceted: a text of a specialty combines general scientific and highly specialized terminology; the text in the specialty provides opportunities for understanding and definition of terms. A scientific text on a specialty provides an opportunity to harmoniously combine exercises in the process of learning to develop language skills and work with a scientific 
text" [7, p. 2]. Thus, working with the text on the specialty is the main part of the training of students in the classes of language of education in the 1 st-5th years of study.

At the basic and advanced stages of work with students the text becomes the leading unit of complex training, therefore questions of providing classes with text material and constant updating of this base of texts are always in the focus of the teacher. Scientific text should be a source of relevant, professionally significant information. Texts should give the teacher an opportunity to use them in the classroom as material for observation, analysis, comprehension, training of speech skills, as well as control of the material studied.

Unfortunately, a teacher of language of education at a technical university has to work under conditions of lack of textbooks and teaching materials for foreign students studying a certain engineering or architectural specialty. In most cases, there are no textbooks with texts relevant to teaching foreign students of a certain level of proficiency in language of education yet. That is why the teacher is forced to choose texts for classes by himself/herself.

The question of text selection is one of the most important for teachers working with students. Working with a special technical scientific text in language classes is an important motivating factor of language learning for foreign students. The use of such texts considerably intensifies their learning activity. The choice of one or another type of text is determined by the level of language proficiency of the study group and the goals of the lesson, connections with the specialty, information richness of the text.

Undoubtedly, the selection of texts requires consultation with the teachers of the major departments, acquaintance with textbooks and tutorial for the special disciplines in which foreign students study in the major courses. But, as M.N. Nayfeld rightly points out, "Unfortunately, in teaching practice... students in the language class are offered what is important from the perspective of the subject teacher, not what is important for the realization of a specific language learning goal at a given stage. The teacher in these conditions turns into a tutor in a non-fiction discipline, is engaged in the formation of subject competence, which is not at all part of his function" $[8$, p. 30].

The learning of highly specialized lexis is not the goal of the language class. Its comprehension and memorization in the main disciplines is promoted by high repetition in specialty textbooks. The main thing when working with a scientific text in language of education classes is to solve a certain communicative problem. It is inexpedient to teach texts containing only highly specialized vocabulary. This does not mean that you should refuse specialized texts, but the student must first get universal information from the class, which can be used when working with other specialized texts.

Thus, in classes must be used primarily model texts, characterized by the presence of a common to several texts communicative intent, structural and syntactic models, allowing its use as a unit of learning.

In the thematic plan of studying the discipline "Ukrainian (Russian) as a foreign language" at our university, classes are grouped by topics. For example, the first content module in the second year of study includes the linguistic topic: "Expression of circumstantial relations". This topic contains such subtopics - "Educational and Professional Sphere: "Old Russian Art (mosaics, frescoes, icon painting)" and "Social and Cultural Sphere: "Kievan Rus". Classes are timed to coincide as much as possible with the study of these topics in the main disciplines.
Work with texts on engineering/architectural topics in the specialty usually consists of the following steps:

1. Pre-textual tasks, the purpose of which is to remove difficulties of understanding and reading a specialty text. These are tasks on semantization of vocabulary, first of all terminological, development of language guessing, grammar repetition, setting tasks while reading the text.

2. Reading of the text.

3. Post-text exercises, providing for control of assimilation and understanding of the studied material. These are question-and-answer exercises, making a plan of the text, outlining, retelling the text $[9$, c. 10].

As an example, we will work with the text on the specialty with second-year students.

Before reading and working with the text a complex of tasks is offered that not only explain the new material, but also activate the students' language experience necessary to read this text. The main task of the pre-text block is to eliminate lexical and grammatical difficulties. Here tasks of different types can be used.

- tasks to eliminate lexical difficulties (Write new words and word combinations...);

- tasks to work with the key words of the text (Give names to pictures, put these words into sentences...);

- tasks to recognize words by their formal and semantic features (Put questions to words, decompose words...);

- tasks on word formation (Analyze the chains of word formation, determine the meaning of the suffix ...);

- tasks to recognize grammatical constructions (Change the sentences according to the sample...);

- tasks to improve grammatical skills (Change nouns and word combinations ...; Conjugate verbs, match verbs with nouns ...; Make word combinations ...).

Pre-text assignments help international students better understand and absorb the material offered. During reading texts on the specialty many difficulties arise and to achieve positive results it is necessary to organize the methodical work correctly.

The communicative purpose of such lessons is the construction of one's own scientific text, because this type of work, as practice shows, is one of the most effective. The result of the work is most often the sounding out of the written text, as well as the independent compilation of a vocabulary of active vocabulary on the topic of the lesson.

In addition, students are offered, for example, a simple name plan of the message and models of scientific style of speech (created by the teacher), which they should use when writing their own text on the specialty. And in strong groups students make the plan and constructions necessary for a monological statement on their own.

In the process of such work on the construction of scientific text on the basis of the plan and models the vocabulary of students is expanded, the skills of constructing a text on the models of scientific style of speech, composing a monological statement are improved. But we pay attention to the fact that at the pretext stage students should also be introduced to a small number of new lexical units, the meaning of which cannot be understood from the text during its reading, as well as some grammatical phenomena that will help students better understand the structure of the text. In addition, in the process of reading the text the teacher should ensure its fullest understanding, drawing stu- 
dents' attention to how the context helps to understand the meanings of unfamiliar words and reveal the content of unknown concepts, And at the post-text work stage it is necessary to actualize the new vocabulary and terminology by performing various tasks aimed at analyzing the meaning of new words and phrases and connected with the peculiarities of their use in speech, to consolidate with students the practical application in various texts and mono-texts.

Conclusions. Thus, systematic work with a text on the specialty is a leading component of students' learning in the language of education classes on the main courses, develops the skills of reproduction and reproduction of texts and contributes to the formation of communicative competence in the professional sphere.

\section{References:}

1. Тохтар Г.І. Проблеми навчання іноземних громадян у ВНЗ України та шляхи їх вирішення / Г.І. Тохтар, А.П. Кулик. Сучасні технології підготовки фахівиів в умовах подальшого розвитку вищої освіти України : матеріали Міжнар. наук-метод. конф. Харків : ХНАДУ, 2005. С. 314-331.

2. Ігнатова В.В., Креч Т.В., Мартинова І.С., Мілєва І.В., Ходаківська М.О. Вивчаємо українську: підручник з української мови як іноземної для студентів спеціальностей 191 «Архітектура та містобудування», 192 «Будівництво та цивільна інженерія». Харків : Видавництво Іванченка І.С., 2019. 324 с.

3. Скрипник Л., Черногорская Н. Шаг в профессию: Практикум по развитию речи для иностранных соискателей высшего образования специальности 192«Строительство и гражданская инженерия». Харьков : ХНУСА, 2020. С. 120.

4. Беликова Е., Бессонова Н., Греул О. Шаг в профессию: Практикум по развитию речи для иностранных соискателей высшего образования специальности 191 «Архитектура и градостроительство». Харьков : ХНУСА, 2020. С. 186.

5. Сокол М., Пахомова Н. Слово и текст: читаем тексты по специальности на уроках РКИ. Вестник НГТУ им. Р.Е. Алексеева. Управление в социальных системах. Коммуникативные технологии». 2015. C. 58-62.

6. Креч Т.В., Мілєва І.В., Ходаківська М.О. Крокуємо до фаху: Практикум з української мови як іноземної : посібник для студентів-іноземців спеціальності 191 «Архітектура та містобудування». Харків : ХНУБА, 2018. 113 с.

7. Мотина Е. Язык и специальность: лингвометодические основы обучения русскому языку студентов-нефилологов. 2-е изд., испр. Москва : Рус. яз., 1988. 176 с.; 22 см.; ISBN 5-200-00053

8. Найфельд М. Пособие для обучения чтению литературы по специальности. Москва : Изд-во Моск. ун-та, 1981. С. 86.

9. Milieva I., Khodakivska M. Methods of reading texts in the field in Ukrainian as a foreign language Visnyk. Taras Shevchenko National university of Kyiv: Pedagogy. 2020. № 1 (11). P. 32-35.
Скрипник Л. В., Ходаківсыка М. О., Черногорська Н. Г. Деякі аспекти роботи 3 текстами у процесі вивчення мови спеціальності в технічному університеті в групах 3 англійською мовою навчання

Анотація. У статті розглядається проблематика роботи 3 текстами за спеціальністю в системі викладання мови навчання в технічному університеті. Метою цього дослідження $€$ аналіз і систематизація основних аспектів і труднощів роботи з текстами за спеціальністю на заняттях із мови навчання в технічному вузі і представлена система роботи 3 конструювання спеціального наукового тексту, яка використовується авторами дослідження.

Оскільки метою підготовки іноземних студентів технічного вузу на заняттях мови навчання є формування комунікативної компетенції, в першу чергу в професійній сфері спілкування, завдання викладачів кафедри полягає в тому, щоб навчити і розвинути здатність в іноземних студентів розуміти і продукувати наукові тексти за фахом. Адже в процесі професійно орієнтованого навчання і відбувається формування особистості майбутнього інженера або архітектора, і ця особистість має бути здатною до продуктивної професійної комунікації як рідною, так і іноземною мовою. Але викладачі мають звертати увагу й на те, що іноземні здобувачі вищої освіти часто показують низький рівень умінь і навичок роботи з професійно орієнтованими текстами як у процесі навчання, так і під час складання іспитів.

Науковий текст за фахом, який є предметом аналізу цього дослідження, дає змогу гармонійно поєднувати в процесі навчання вправи з вироблення навичок оволодіння мовою і роботи з науковим текстом, а також має бути джерелом актуальної, професійно значущої інформації. Тексти мають давати викладачеві змогу використовувати їх на заняттях як матеріал для спостереження, аналізу, осмислення, тренування мовних умінь і навичок, а також контролю вивченого матеріалу. Автори статті зосереджують увагу на самостійній роботі студентів в аудиторії, читанні текстів будь-якого рівня складності, на зрозумінні, а не на відтворенні тексту.

Автори також роблять висновок, що систематична робота 3 текстом за фахом $є$ провідною складовою частиною навчання студентів на заняттях із мови навчання на основних курсах, розвиває навички репродукування та продукування текстів та сприяє формуванню комунікативної компетенції у професійній сфері.

У статті проаналізовано досвід, набутий кафедрою української мови та мовної підготовки іноземних громадян у сфері викладання мови навчання, та визначено перспективи подальшої методичної роботи.

Ключові слова: мова навчання, науковий текст, текст за фахом, професійна комунікація, комунікативна компетенція. 